\title{
Effect of Fish Pond Sludge Waste Materials on the Geotechnical Properties of Soils
}

\author{
Charles Kennedy ${ }^{1 *}$, Ugo Kingsley ${ }^{2}$, Gabriel Okonkwo Nnaji ${ }^{3}$ \\ ${ }^{1}$ Department of Civil Engineering, Faculty of Engineering, Rivers State University, Port Harcourt - Rivers State, Nigeria \\ ${ }^{2}$ School of Engineering, Department of Civil Engineering, Kenule Beeson Saro-Wiwa Polytechnic, Bori, Rivers State, Nigeria. \\ ${ }^{3}$ Department of Civil Engineering, Enugu State University of Science and Technology, Enugu
}

DOI: $\underline{\text { 10.36348/sjet.2020.v05i03.001 }}$ | Received: 22.02.2020 | Accepted: 01.03.2020 | Published: 07.03 .2020

*Corresponding author: Charles Kennedy

\section{Abstract}

The research work investigated the effect of leachate sludge waste materials from fish rearing pond on the geotechnical properties of soils from dumpsites. Results of investigations conducted on the control sites at $30 \mathrm{~m}$ away from each dumpsite of bulk unit weight have incremental percentage values over control sites. Percentage (\%) passing BS sieve \#200 is higher in dumpsites over control with percentile value increase. Obtained results showed the presence of leachate material affects the physical properties of soil as percentages passing sieve \#200 are higher in dumpsite materials. The consistency limits of the control sites of Liquid over plastic limits are summarized into the plastic index (LL-PL=PI), the obtained results indicated reductions values over dumpsites, this indicated that dumpsites leachate materials affected consistency limits of soils with higher values recorded in dumpsites. The entire results of grain size distribution showed that leachate percolation from waste materials affected the distribution properties of soil with dumpsites samples in dominants over control sites. Results indicated reductions in Unconfined compressive strength of control sites, these results showed that the presence of leachate materials has a great effect on soil properties of tested. The California bearing ration results of unsoaked and soaked of dumpsites have higher values over control sites. Results of California bearing ratio obtained showed that the presence of contaminants from waste dumpsites affected the geotechnical properties of tested soil with higher percentage values of dumpsites over control sites. The entire results showed that the presence of fish pond waste sludge has great negative effects on the geotechnical properties of soil.

Keywords: Waste Materials, Geotechnical, soils, dumpsites.

Copyright @ 2020: This is an open-access article distributed under the terms of the Creative Commons Attribution license which permits unrestricted use, distribution, and reproduction in any medium for non-commercial use (NonCommercial, or CC-BY-NC) provided the original author and source are credited.

\section{INTRODUCTION}

The rearing of fishes in diverse cultural media or a confined controlled environment such as ponds made of concrete or earthen, plastics or wooden has alarming numbers[1].Among these cultured systems, concrete and earthen ponds are widely used [2] and all to meet the daily human population and challenges. Sludge generated from these practices is made up of various organic materials that end up at the bottom of ponds mixed with some of the various inorganic resulting from artificial feeds. The precise makeup of sludge depends greatly on what's in and around the pond, of course. Lately, the earthen ponding system was the conventional method, but of recent, reinforced concrete and concrete block tanks have dominated the fish rearing culture. Sewage sludge is that the suspension residue derived from wastewater treatment processes. Tons of exacting controls on the quality of effluent discharges have given rise to larger volumes of the sludge for disposal. Principal disposal routes embody agricultural employment and land restoration or sludge-to-landfill operations, either co--disposal at municipal landfills or mono disposal at dedicated sites. The sludge ought to be adequately dried or dewatered to engineer, as associate degree example, the economical handling and trafficability by machine plant, optimum compaction, associated degree adequate issue of safety against slope instability for the sludge-to-landfill route. The dewatered sludge is also a soil-like material, and, as such, its performance at intervals the lowland area unit usually modeled victimization soil mechanics theory and knowledge of the drying, shear strength, and consolidation properties of the compacted material. Geotechnical properties unit of measurement presented that, once applied to the planning of a sludge monofill, will facilitate minimize potential environmental hazards by increasing lowland stability and dominant leachate and biogas generation at intervals the strategy, 
these procedures will maximize the storage capability and, hence, the operational life of a given sludge monofil. The lowland trend ought to realize the implications of digestion on the engineering properties of the sludge material once determining the semipermanent issue of safety against the instability of the lowland slopes.

Researches revealed that fish farmers preferred concrete method and $73 \%$ of ponds in Port Harcourt is made of concrete while $27 \%$ are of earthen ponds[3, 4].

Fish harvested from the controlled concrete tanks have high deposits of sludge [5], reported on contamination resulting from water quality and high stocking densities. The feed consumed by the fishes contained organic materials with varieties of microorganisms into the ponds [6].

Due to the number of ponds present, the generation of sludge is high which has resulted in indiscriminate dumping. The waste (sludge), as a result of lack of proper environmental planning, have contact with the soil, decomposed and reacts to the soil and thereby contaminating the soil and affecting the geoenvironmental and geotechnical properties of the soil. The result of the contaminative nature affects the geotechnical properties of the soil which makes the soil becomes plastic, shrinkage, compressible and low shear strength and low California Bearing Ratio. When soils are to be used for engineering activities such as foundation support for roads, building, and structural elements, it is very viable to develop economical and technically feasible solutions to reinforce/stabilized the poorest type of soil.

\section{MATERIALS AND METHODS}

\section{Study Area Description and Sampling Locality}

The study areas are in Obio/Akpor Local Government Areas of Rivers, namely; Rukpoku dumpsite laying between Longitudes $7^{\circ} .00$ ' $15^{\prime \prime} \mathrm{E}$ and latitudes $4^{\circ} .90^{\prime} 36^{\prime \prime} \mathrm{N}$, Igwuruta between Longitudes $7^{\circ} .01$ '36" E and latitudes $4^{\circ} .95^{\prime} 64^{\prime \prime} \mathrm{N}$, and Rumuokoro between Longitudes 60.98 '80" E and latitudes $4^{\circ} .86^{\prime} 51^{\prime \prime} \mathrm{N}$ in the Niger Delta of South-South of Nigeria.

\section{Sample Collections \\ Collection of soil sample}

Soil samples were collected from the dumpsites using hand-dug agar, sampled on $150 \mathrm{~mm}$ farmland before sampling, sealed in plastic bags and placed in plastics to prevent moisture loss during transport. Samples collected at a depth of $1800 \mathrm{~mm}$, and after 7 days of air drying, the optimal capacity of the deltaic soil can be assessed [7-9].

Geotechnical laboratory analysis of soil properties was performed to determine the physical properties; New and clean cellophane bags with specific gravity, humidity, fine particle percentage, liquid limit, plastic limit, plasticity index, optimum humidity, maximum dry density and heavy metal levels in individual profiles. Samples were immediately sent to the laboratory for analysis

Conducted tests included (1) Moisture Content Determination (2) Atterberg limits test (3) Particle size distribution (sieve analysis) and (4) Standard Proctor Compaction test, (5) California Bearing Ratio test (CBR) and (6) Unconfined compressive strength (UCS) tests.

\section{Moisture Content Determination}

The natural moisture content of the soil obtained from the site was determined by BS 1377 (1990) Part 2. The freshly assembled sample was laminated and kept loose in the container, and the containers containing the specimens were weighted together. $0.01 \mathrm{~g}$.

\section{Grain Size Analysis (Sieve Analysis)}

This test is done to determine the percentage of different grain sizes present in the soil. Mechanical or sieve analysis is performed to determine the distribution of coarse, large-sized particles larger-sized particles.

\section{Atterberg Limits}

This test is performed to determine the plastic and liquid boundaries of fine-grained soil. Liquid limit (LL) is defined as arbitrary water content, in which a portion of the soil in a standard cup and a standard measuring groove is cut because a distance of $13 \mathrm{~mm}$ flows simultaneously into the canal (1/2 in.) with two shocks per second, $25 \mathrm{~mm}$ from the cup. Plastic restriction (PL) is the amount of water, in percentage, that cannot hold soil without breaking it into pieces with a diameter of $3.2 \mathrm{~mm}$ (1/8 inch).

\section{Moisture - Density (Compaction) Test}

This laboratory test is performed to determine the relationship between moisture and soil dry density for the specified compact effort. Compact effort means mechanical force applied to the mass of the soil. There are many different techniques used to compact the soil in the field, and some examples are tamping, kneading, and static load capture. In 1933, the lab at the RK The type and method of equipment developed by R. Proctor uses the tamping or impact condensation method, therefore, the test is also called the proctor test.

\section{Unconfined Compression (UC) Test}

The primary objective of this test is to determine unconfined compressive strength, which is then used to calculate the uniform shear strength of the soil under exceptional conditions. According to the ASTM standard, unconfined compressive strength is defined as compressive stress in which unrefined cylindrical clay fails the normal compression test. Also, in this test method, the unconfined compressive strength is taken as the maximum load attained per unit area, or 
the load per unit area at $15 \%$ axial strain, whichever occurs first during the performance of a test.

\section{California Bearing Ratio (CBR) Test}

The California Bearing Ratio (CBR) test was developed by the California Division of Highways as a method of classifying and evaluating soil- subgrade and base course materials for flexible pavements. CBR is a measure of the resistance of a material to penetration.

\section{RESULTS OF INVESTIGATION}

Results of investigations conducted on the control sites, 30m away from each dumpsite of Bulk Unit Weight have incremental percentile values of $63.24466 \%, 63.09872 \%$ and $50.78086 \%$ over control sites $36.75534 \%, 36.90128 \%$, and $49.21914 \%$. The results indicated a rise in bulk densities due to the presence of leachate materials percolation into the soil.

Percentages (\%) passing BS sieve \#200 are higher in dumpsites over control with percentile value increase of $100.9165 \%, 64.84465 \%$ and $74.77857 \%$ over $-0.9165 \%, 35.15535 \&$ and 25.22143 , obtained results showed the presence of leachate material affects the physical properties of soil as percentages passing sieve \#200 are higher in dumpsite materials.

The specific gravity percentile values decreases in dumpsites with percentage values of $54.282 \%,-23.9206 \%$ and $-11.0517 \%$ against $154.282 \%$, $123.9206 \%$ and $111.0517 \%$. This showed the influence of leachate materials does not affect the specific gravity of soils.

The natural moisture content $(\%)$ of soils as affected by leachate waste with percentage differences of $71.22015 \%, 57.94135 \%$ and $75.06732 \%$ overcontrolled samples of $28.77985 \%, 42.05865 \%$, and $24.93268 \%$.

The consistency limits of the control sites of Liquid over plastic limits are summarized into plastic index (LL-PL=PI) are percentage values of $-30.6681 \%$, $-47.5502 \%$ and $-44.439 \%$ against $130.6681 \%$,
$147.5502 \%$ and $144.439 \%$ of controlled sites, obtained results indicated reductions values over dumpsites, this indicated that dumpsites leachate materials affected consistency limits of soils with higher values recorded in dumpsites. The Compaction Characteristics of dumpsites are not affected.

The Grain Size Distribution of analyzed samples was affected by leachate material percolation with higher distributions in dumpsites of gravel; $152.8444 \%, 152.2619 \%, 141.5673 \%$ over control sites of $-52.8444 \%,-52.2619 \%,-41.5673$. Sand distributions are; $141.7795 \%, 145.6778 \%, 163.6071 \%$ over control sites of $-41.7795 \%,-45.6778 \%,-63.6071 \%$. Silt distributions are; $154.8001 \%, 181.898 \%, 210.139 \%$ over control sites of $-54.8001 \%,-81.898 \%,-110.139 \%$. Clay size distributions are $136.7024 \%, 134.179 \%$, $130.7075 \%$ over control sites of $-36.7024 \%,-34.179 \%$ and $-30.7075 \%$.

The entire results of grain size distribution showed that leachate percolation from waste materials affected the distribution properties of soil with dumpsites samples in dominants over control sites. The Unconfined compressive strength of sampled soils from dumpsites is $155.4973 \%, 120.3358 \%, 121.7354 \%$ over control sites of $-55.4973 \%,-20.3358 \%$ and $-21.7354 \%$.

Results indicated reductions in unconfined compressive strength of control sites, these results showed that the presence of leachate materials has a great effect on soil properties of tested.

The California bearing ration results of unsoaked of dumpsites are $280.556 \%, 352.161 \%$, $299.385 \%$ over control sites of $-180.556 \%,-252.161 \%$ and -199.385 while soaked CBR for dumpsites are $273.19 \%, 305.717 \%, 195.3577 \%$ and control sites are $173.19 \%,-205.717 \%,-95.3577 \%$. Results of California bearing ratio obtained showed that the presence of contaminants from waste dumpsites affected the geotechnical properties of tested soil with higher percentage values of dumpsites over control sites.

Table-3.1: Engineering Physical Analysis of Soil Samples at the Dumpsite

\begin{tabular}{|c|c|c|c|c|c|c|}
\hline \multirow[t]{2}{*}{ Description } & \multicolumn{2}{|c|}{$\begin{array}{c}\text { Rukpoku } \\
\text { (Laterite Soil) } \\
\text { Site } 1 \\
\end{array}$} & \multicolumn{2}{|c|}{$\begin{array}{c}\text { Igwuruta Dumpsite (Laterite } \\
\text { Soil) } \\
\text { Site } 2 \\
\end{array}$} & \multicolumn{2}{|c|}{$\begin{array}{c}\text { Rumuokoro Dumpsite (Laterite } \\
\text { Soil) } \\
\text { Site3 } \\
\end{array}$} \\
\hline & Control & Dumpsite & Control & Dumpsite & Control & Dumpsite \\
\hline Depth of sampling (m) & 1.8 & 1.8 & 1.8 & 1.8 & 1.8 & 1.8 \\
\hline Bulk Unit Weight $\left(\mathrm{kN} / \mathrm{m}^{3}\right)$ & 13.9 & 16.2 .4 & 13.1 & 15.3 & 12.7 & 14.4 \\
\hline (\%) passing BS sieve \#200 & 33.5 & 42.7 & 35.3 & 41.4 & 31.9 & 38.3 \\
\hline Color & \multicolumn{2}{|c|}{ Reddish } & \multicolumn{2}{|c|}{ Reddish } & \multicolumn{2}{|c|}{ Reddish } \\
\hline Specific gravity & 2.55 & 2.23 & 2.59 & 2.44 & 2.57 & 2.50 \\
\hline Natural moisture content $(\%)$ & 29.9 & 35.6 & 33.2 & 38.3 & 27.8 & 33.4 \\
\hline \multicolumn{7}{|c|}{ Consistency Limits } \\
\hline Liquid limit (\%) & 35.9 & 31.4 & 42.7 & 38.4 & 39.3 & 34.6 \\
\hline Plastic limit (\%) & 22.3 & 18.8 & 29.2 & 26.4 & 27.8 & 24.3 \\
\hline Plasticity Index & 13.6 & 12.6 & 13.5 & 12.0 & 11.5 & 10.3 \\
\hline
\end{tabular}


Charles Kennedy et al., Saudi J Eng Technol, March. 2020; 5(3): 94-100

\begin{tabular}{|c|c|c|c|c|c|c|c|}
\hline \hline AASHTO soil classification & A-2-6 & A-2-6 & A-2-6 & A-2-6 & A-2-6 & A-2-6 \\
\hline \multicolumn{7}{|c|}{ Compaction Characteristics } \\
\hline Optimum moisture content (\%) & 15.8 & 13.8 & 17.7 & 14.5 & 14.7 & 11.3 \\
\hline Maximum dry density $\left(\mathrm{kN} / \mathrm{m}^{3}\right)$ & 1.72 & 1.57 & 1.84 & 1.69 & 1.63 & 1.51 \\
\hline \multicolumn{7}{|c|}{ Grain Size Distribution } \\
\hline Gravel (\%) & 4.9 & 4.3 & 6.6 & 5.8 & 5.1 & 4.6 \\
\hline Sand (\%) & 33.5 & 30.2 & 38.3 & 34.2 & 43.5 & 37.2 \\
\hline Silt (\%) & 37.1 & 39.5 & 27.7 & 29.8 & 17.6 & 21.5 \\
\hline Clay (\%) & 24.5 & 26.6 & 27.4 & 30.2 & 33.8 & 36.7 \\
\hline \multicolumn{7}{|c|}{ Unconfined compressive strength } \\
\hline $\begin{array}{l}\text { Unconfined compressive } \\
\text { strength (kPa) }\end{array}$ & 147.6 & 128.7 & 155.6 & 147.9 & 168.6 & 159.7 \\
\hline \multicolumn{7}{|c|}{ California Bearing Capacity (CBR) } \\
\hline Unsoaked (\%) CBR & 13.2 & 8.8 & 14.4 & 8.5 & 14.9 & 9.6 \\
\hline Soaked (\%) CBR & 10.8 & 7.3 & 11.3 & 7.2 & 10.7 & 8.5 \\
\hline
\end{tabular}

Table-3.2: Control and Dumpsites Obtained Values Difference and Percentile Value

\begin{tabular}{|c|c|c|c|c|c|c|c|c|c|c|c|c|}
\hline & \multicolumn{6}{|c|}{$\begin{array}{c}\text { Control and Dumpsites Obtained Values } \\
\text { Difference }\end{array}$} & \multicolumn{6}{|c|}{ Control and Dumpsite Percentile Value } \\
\hline & \multicolumn{2}{|c|}{ Site 1} & \multicolumn{2}{|c|}{ Site 2} & \multicolumn{2}{|c|}{ Site 3} & \multirow{2}{*}{ 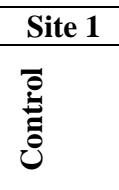 } & \multirow{2}{*}{ 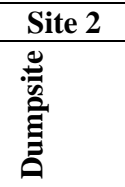 } & \multirow{2}{*}{$\begin{array}{l}\text { Site } 3 \\
\bar{e} \\
\bar{\Xi}\end{array}$} & \multirow{2}{*}{ 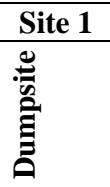 } & \multirow{2}{*}{ 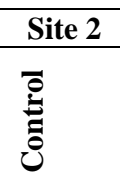 } & \multirow{2}{*}{ 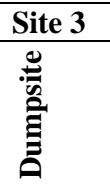 } \\
\hline & $\stackrel{\bar{\Xi}}{\vec{\theta}}$ & 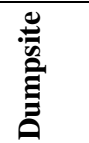 & 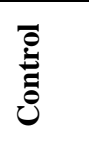 & 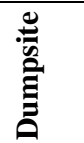 & $\underset{\dot{E}}{\bar{\Xi}}$ & 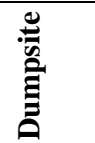 & & & & & & \\
\hline $\begin{array}{l}\text { Bulk Unit } \\
\text { Weight } \\
\text { (kN/m3) }\end{array}$ & 0.856 & 1.168 & 0.856 & 1.168 & 0.882 & 1.134 & 85.591 & 116.835 & 85.621 & 116.794 & 88.194 & 113.386 \\
\hline $\begin{array}{l}\text { Percentage }(\%) \\
\text { passing BS } \\
\text { sieve \#200 }\end{array}$ & 0.785 & 1.275 & 0.853 & 1.173 & 0.833 & 1.201 & 78.454 & 127.463 & 85.266 & 117.281 & 83.290 & 120.063 \\
\hline Specific gravity & 1.143 & 0.875 & 1.061 & 0.942 & 1.028 & 0.973 & 114.350 & 87.451 & 106.148 & 94.208 & 102.800 & 97.276 \\
\hline \multirow[t]{2}{*}{$\begin{array}{l}\text { Natural } \\
\text { moisture } \\
\text { content }(\%)\end{array}$} & 0.840 & 1.191 & 0.867 & 1.154 & 0.832 & 1.201 & 83.989 & 119.064 & 86.684 & 115.361 & 83.234 & 120.144 \\
\hline & \multicolumn{12}{|c|}{ Consistency Limits } \\
\hline $\begin{array}{l}\text { Liquid limits } \\
(\%)\end{array}$ & 1.143 & 0.875 & 1.112 & 0.899 & 1.136 & 0.880 & 114.331 & 87.465 & 111.198 & 89.930 & 113.584 & 88.041 \\
\hline $\begin{array}{l}\text { Plastic limits } \\
(\%)\end{array}$ & 1.186 & 0.843 & 1.106 & 0.904 & 1.144 & 0.874 & 118.617 & 84.305 & 110.606 & 90.411 & 114.403 & 87.410 \\
\hline \multirow[t]{2}{*}{$\begin{array}{l}\text { Plasticity limits } \\
(\%)\end{array}$} & 1.079 & 0.926 & 1.125 & 0.889 & 1.117 & 0.896 & 107.937 & 92.647 & 112.500 & 88.889 & 111.651 & 89.565 \\
\hline & \multicolumn{12}{|c|}{ Compaction Characteristics } \\
\hline $\begin{array}{l}\text { Optimum } \\
\text { moisture } \\
\text { content }(\%)\end{array}$ & 1.145 & 0.873 & 1.221 & 0.819 & 1.301 & 0.769 & 114.493 & 87.342 & 122.069 & 81.921 & 130.089 & 76.871 \\
\hline $\begin{array}{l}\text { Maximum dry } \\
\text { density }(\mathrm{kN} / \mathrm{m} 3)\end{array}$ & 1.096 & 0.913 & 1.089 & 0.918 & 1.079 & 0.926 & 109.554 & 91.279 & 108.876 & 91.848 & 107.947 & 92.638 \\
\hline & \multicolumn{12}{|c|}{ Grain Size Distribution } \\
\hline Gravel (\%) & 1.140 & 0.878 & 1.138 & 0.879 & 1.109 & 0.902 & 113.954 & 87.755 & 113.793 & 87.879 & 110.870 & 90.196 \\
\hline Sand $(\%)$ & 1.109 & 0.901 & 1.120 & 0.893 & 1.169 & 0.855 & 110.927 & 90.149 & 111.988 & 89.295 & 116.936 & 85.517 \\
\hline Silt (\%) & 0.939 & 1.065 & 0.930 & 1.076 & 0.819 & 1.222 & 93.924 & 106.469 & 92.953 & 107.581 & 81.860 & 122.159 \\
\hline \multirow[t]{2}{*}{ Clay (\%) } & 0.921 & 1.086 & 0.907 & 1.102 & 0.921 & 1.086 & 92.105 & 108.571 & 90.728 & 110.219 & 92.098 & 108.580 \\
\hline & \multicolumn{12}{|c|}{ Unconfined compressive strength } \\
\hline \multirow[t]{2}{*}{$\begin{array}{l}\begin{array}{l}\text { Unconfined } \\
\text { compressive } \\
\text { strength }(\mathrm{kPa}\end{array} \\
\end{array}$} & 1.147 & 0.872 & 1.052 & 0.951 & 1.056 & 0.947 & 114.685 & 87.195 & 105.206 & 95.051 & 105.573 & 94.721 \\
\hline & \multicolumn{12}{|c|}{ California Bearing Capacity (CBR) } \\
\hline $\begin{array}{l}\text { Unsoaked (\%) } \\
\text { CBR }\end{array}$ & 1.500 & 0.667 & 1.694 & 0.590 & 1.552 & 0.644 & 150.000 & 66.667 & 169.412 & 59.028 & 155.208 & 64.430 \\
\hline $\begin{array}{l}\text { Soaked (\%) } \\
\text { CBR }\end{array}$ & 1.479 & 0.676 & 1.569 & 0.637 & 1.259 & 0.794 & 147.945 & 67.593 & 156.944 & 63.717 & 125.882 & 79.439 \\
\hline
\end{tabular}


Charles Kennedy et al., Saudi J Eng Technol, March. 2020; 5(3): 94-100

\begin{tabular}{|c|c|c|c|c|c|c|c|c|c|c|c|c|}
\hline \multicolumn{13}{|c|}{ Table-3.3: Control and Dumpsites Obtaine } \\
\hline 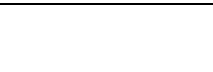 & \multicolumn{6}{|c|}{$\begin{array}{l}\text { Control and Dumpsites Obtained Values } \\
\text { Difference }\end{array}$} & \multicolumn{6}{|c|}{ Control and Dumpsite Percentile Value Difference } \\
\hline & \multicolumn{2}{|c|}{ Site 1} & \multicolumn{2}{|c|}{ Site 2} & \multicolumn{2}{|c|}{ Site 3} & \multirow{2}{*}{ 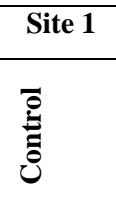 } & \multirow{2}{*}{ 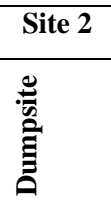 } & \multirow{2}{*}{ 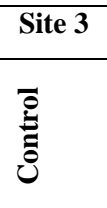 } & \multirow{2}{*}{ 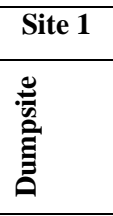 } & \multirow{2}{*}{$\begin{array}{l}\text { Site } 2 \\
\tilde{0} \\
\tilde{\Xi}\end{array}$} & \multirow{2}{*}{ 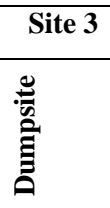 } \\
\hline & $\bar{\Xi}$ & :气 & i் & 产 & ن் & 产 & & & & & & \\
\hline $\begin{array}{c}\text { Bulk Unit } \\
\text { Weight }(\mathrm{kN} / \mathrm{m} 3)\end{array}$ & 0.856 & 1.168 & 0.856 & 1.168 & 0.882 & 1.134 & 63.245 & 36.755 & 63.099 & 36.901 & 50.781 & 49.219 \\
\hline $\begin{array}{c}\text { Percentage }(\%) \\
\text { passing BS } \\
\text { sieve \#200 }\end{array}$ & 0.785 & 1.275 & 0.853 & 1.173 & 0.833 & 1.201 & 100.917 & -0.917 & 64.845 & 35.155 & 74.779 & 25.221 \\
\hline Specific gravity & 1.143 & 0.875 & 1.061 & 0.942 & 1.028 & 0.973 & -54.282 & 154.282 & $\begin{array}{c}- \\
23.921\end{array}$ & 123.921 & -11.052 & 111.052 \\
\hline \multirow[t]{2}{*}{$\begin{array}{c}\text { Natural } \\
\text { moisture content } \\
(\%) \\
\end{array}$} & 0.840 & 1.191 & 0.867 & 1.154 & 0.832 & 1.201 & 71.220 & 28.780 & 57.941 & 42.059 & 75.067 & 24.933 \\
\hline & \multicolumn{12}{|c|}{ Consistency Limits } \\
\hline $\begin{array}{l}\text { Liquid limits } \\
(\%)\end{array}$ & 1.143 & 0.875 & 1.112 & 0.899 & 1.136 & 0.880 & -54.215 & 154.215 & $\begin{array}{c}- \\
42.776 \\
\end{array}$ & 142.776 & -51.501 & 151.501 \\
\hline $\begin{array}{l}\text { Plastic limits } \\
(\%)\end{array}$ & 1.186 & 0.843 & 1.106 & 0.904 & 1.144 & 0.874 & -69.627 & 169.627 & $-\overline{-}$ & 140.596 & -54.476 & 154.476 \\
\hline \multirow[t]{2}{*}{$\begin{array}{l}\text { Plasticity limits } \\
(\%)\end{array}$} & 1.079 & 0.926 & 1.125 & 0.889 & 1.117 & 0.896 & -30.668 & 130.668 & $-\overline{-}$ & 147.550 & -44.439 & 144.439 \\
\hline & \multicolumn{9}{|c|}{ Compaction Characteristics } & & & \\
\hline $\begin{array}{c}\text { Optimum } \\
\text { moisture content } \\
(\%)\end{array}$ & 1.145 & 0.873 & 1.221 & 0.819 & 1.301 & 0.769 & -54.800 & 154.800 & $\begin{array}{c}- \\
81.898\end{array}$ & 181.898 & -110.139 & 210.139 \\
\hline $\begin{array}{c}\text { Maximum dry } \\
\text { density }(\mathrm{kN} / \mathrm{m} 3)\end{array}$ & 1.096 & 0.913 & 1.089 & 0.918 & 1.079 & 0.926 & -36.702 & 136.702 & $\begin{array}{c}- \\
34.179 \\
\end{array}$ & 134.179 & -30.708 & 130.708 \\
\hline & \multicolumn{12}{|c|}{ Grain Size Distribution } \\
\hline Gravel (\%) & 1.140 & 0.878 & 1.138 & 0.879 & 1.109 & 0.902 & -52.844 & 152.844 & 52.262 & 152.262 & -41.567 & 141.567 \\
\hline Sand $(\%)$ & 1.109 & 0.901 & 1.120 & 0.893 & 1.169 & 0.855 & -41.780 & 141.780 & $\begin{array}{c}- \\
45.678 \\
\end{array}$ & 145.678 & -63.607 & 163.607 \\
\hline Silt (\%) & 0.939 & 1.065 & 0.930 & 1.076 & 0.819 & 1.222 & 25.139 & 74.861 & 29.335 & 70.665 & 82.217 & 17.783 \\
\hline \multirow[t]{2}{*}{ Clay $(\%)$} & 0.921 & 1.086 & 0.907 & 1.102 & 0.921 & 1.086 & 33.044 & 66.956 & 39.166 & 60.834 & 33.075 & 66.925 \\
\hline & \multicolumn{12}{|c|}{ Unconfined compressive strength } \\
\hline \multirow[t]{2}{*}{$\begin{array}{l}\text { Unconfined } \\
\text { compressive } \\
\text { strength }(\mathrm{kPa} \\
\end{array}$} & 1.147 & 0.872 & 1.052 & 0.951 & 1.056 & 0.947 & -55.497 & 155.497 & $20 . \overline{336}$ & 120.336 & -21.735 & 121.735 \\
\hline & \multicolumn{12}{|c|}{ California Bearing Capacity (CBR) } \\
\hline $\begin{array}{l}\text { Unsoaked }(\%) \\
\text { CBR }\end{array}$ & 1.500 & 0.667 & 1.694 & 0.590 & 1.552 & 0.644 & -180.55 & 280.556 & $\begin{array}{c}- \\
252.16 \\
\end{array}$ & 352.161 & -199.385 & 299.385 \\
\hline $\begin{array}{l}\text { Soaked (\%) } \\
\text { CBR }\end{array}$ & 1.479 & 0.676 & 1.569 & 0.637 & 1.259 & 0.794 & -173.19 & 273.190 & $\begin{array}{c}- \\
205.71 \\
\end{array}$ & 305.717 & -95.358 & 195.358 \\
\hline
\end{tabular}

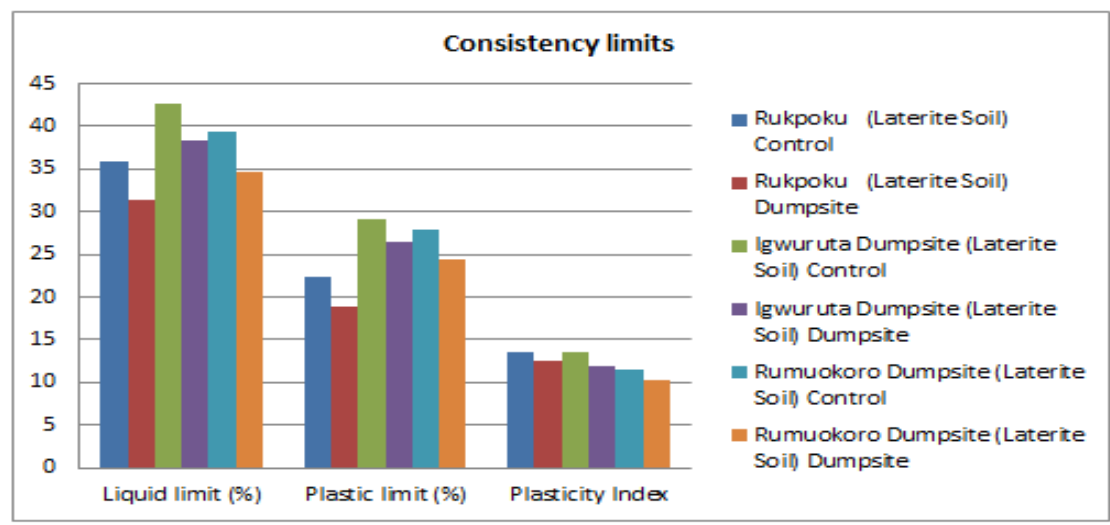

Fig-3.1: Consistency Limits of Control and Dumpsites 


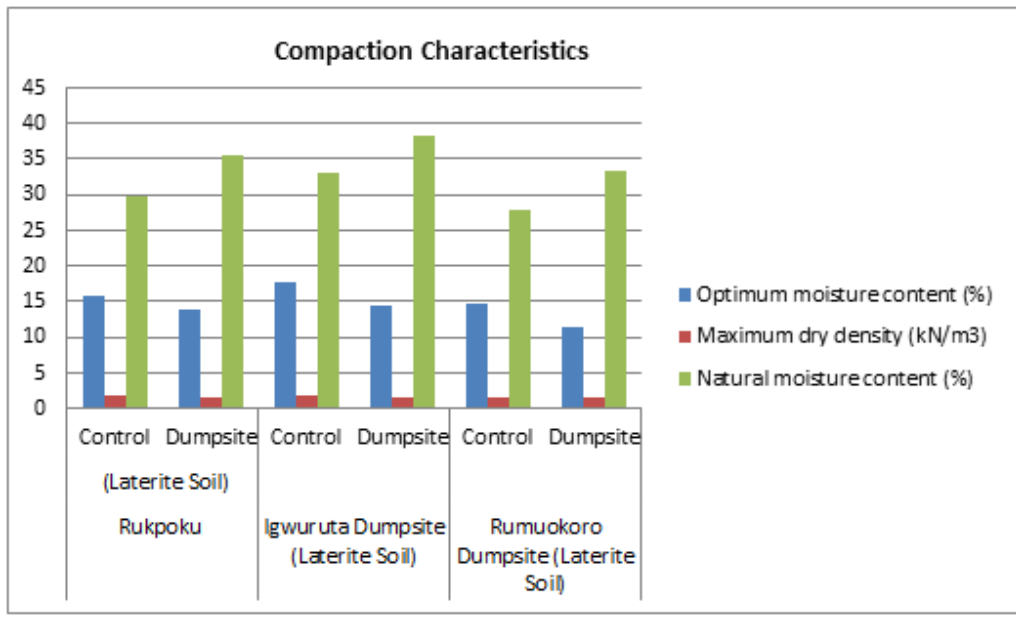

Fig-3.2: Compaction of Control and Dumpsites

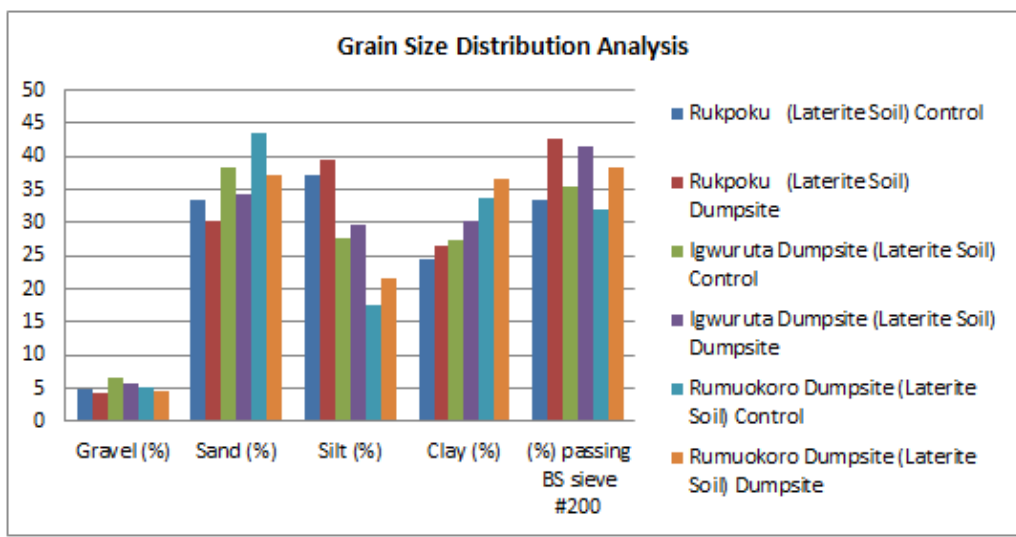

Fig-3. 3: Grain Size Distribution Analysis of Control and Dumpsites

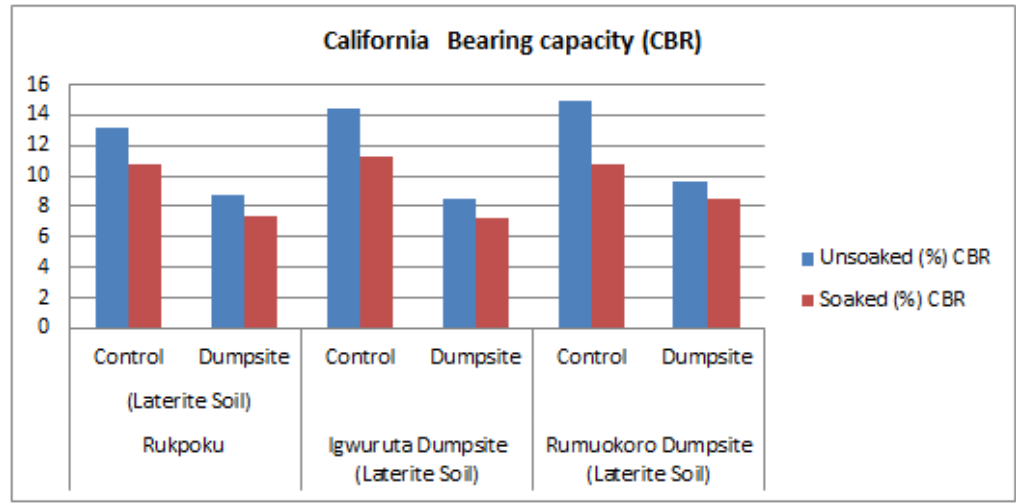

Fig-3.4: California bearing ratio of Control and Dumpsites

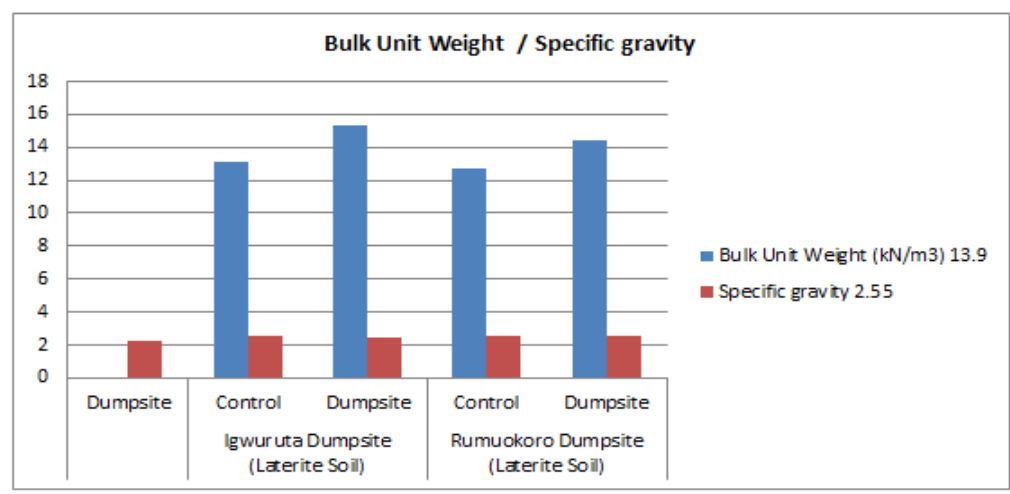

Fig-3.5: Bulk Unit Weight / Specific gravity of Control and Dumpsites 


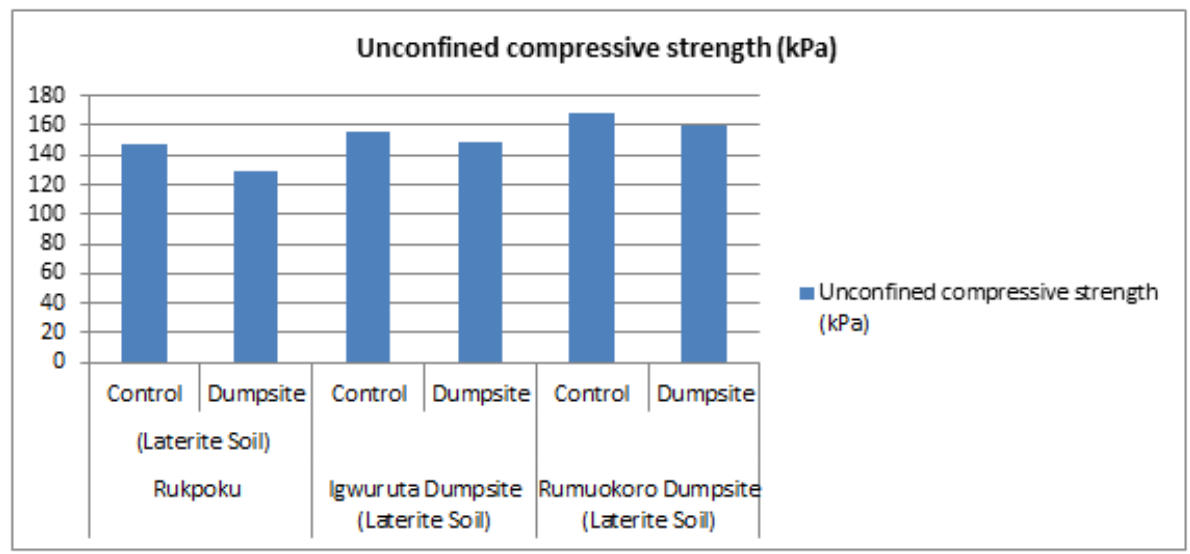

Fig-3.6: Unconfined compressive strength (kPa) of Control and Dumpsites

\section{CONCLUSION}

The below conclusions were drawn from the research results

1. The results indicated a rise in bulk densities due to the presence of leachate materials percolation.

2. Obtained results showed the presence of leachate material affects the physical properties of soil as percentages passing sieve \#200 are higher in dumpsite materials.

3. This showed the influence of leachate materials does not affect the specific gravity of soils.

4. Obtained results indicated reductions values over dumpsites; this indicated that dumpsites leachate materials affected consistency limits of soils with higher values recorded in dumpsites.

5. The entire results of grain size distribution showed that leachate percolation from waste materials affected the distribution properties of soil with dumpsites samples in dominants over control sites.

6. Results indicated reductions in Unconfined compressive strength of control sites, these results showed that the presence of leachate materials has a great effect on soil properties of tested.

7. Results of California bearing ratio obtained showed that the presence of contaminants from waste dumpsites affected the geotechnical properties of tested soil with higher percentage values of dumpsites over control sites.

\section{REFERENCE}

1. Osawe, M. (2004). Catfish fingerlings production management Techniques. Success AttitudeDevelopment center, (SADC) Lagos, Nigeria. Workshop paper, 32

2. Ezenwa, B.I. O. (2006). Aquaculture research and fish farm development potentials in the Niger
Delta. Paper presented at a workshop on Niger Delta fisheries potentials. 10th to

May 2006. Port Harcourt, Nigeria, 1-12

3. Ezenwa, B. I. O. (2006). Aquaculture research and fish farm development potentials in the Niger Delta. Paper presented at a workshop on Niger Delta fisheries potentials. 10th to May 2006. Port Harcourt, Nigeria, 1-12

4. Ugwumba, O.C. (2010). Profitability and Technical Efficiency of Catfish production in

Anambra State Nigeria. Ph. D Dissertation, Department of Agricultural Economics and Extension, Delta State University, Abraka, Nigeria, 63.

5. Okpokwasili G. C., \& Ogbulie, J.N. (1998). Bacterial and metal quality of tilapia (oreochromia nilotica) in aquaculture system. International Journal of Enviromenntal Health Research, 3:190202.

6. Okpokwasili, G.C., \& Ogbulie, J.N. (1999). Microbial and proximate composition of fish feed used in Nigeria aquaculture. Journal of Nature and Science Count of Sri lanka.

7. Ola, S. A. (1974). Need for estimated cement requirements for stabilising lateritic soils. Journal of Transportation Engineering, ASCE, 100(2):379388

8. Allam, M. M., \& Sridharan, A. (1981). Effect of repeated wetting and drying on shear strength.Journal of Geotechnical Engineering, ASCE, 107(4):421-438.

9. Omotosho, P.O., \& Akinmusuru, J .O. (1992). Behaviour of soils (lateritic) subjected to multicyclic compaction. Engineering Geology, 32, 5358 . 